\begin{tabular}{cc}
\hline Jurnal Pendidikan Biologi $8(1)(2018) 6-13$ \\
\hline
\end{tabular}

\title{
Pengembangan Media Pembelajaran Berbasis MindManager Konsep Struktur dan Fungsi Organ Tumbuhan pada Siswa Sekolah Menengah Pertama
}

\author{
Nurlia \& Sulasmi Anggo \\ Program Studi pendidikan Biologi, Fakultas keguruan dan Ilmu Pendidikan, Universitas Muhammadiyah Luwuk, Jl. \\ K.H. Ahmad Dahlan No. 79 Lingkungan III, Telp. (0461) 23452, Fax (0461) 21725 Luwuk, 94711, Kabupaten \\ Banggai, Sulawesi Tengah, Indonesia
}

\section{INFO ARTIKEL}

\section{Histori Artikel}

Received 5 Nopember 2018

Revised 1 Desember 2018

Accepted 3 Desember 2018

Published 8 Desember 2018

\section{Keywords:}

Development of Instructional

Media,

MindManager,

Structure and Function of

Plant Organ

\begin{abstract}
This study is are search and development, which aims to produce instructional media, based MindManager that valid, practical and effective. The subjects were eighth-grade students of SMP 27 Makassar by the number of students 39 people. This study uses research and development according to Borg and Gall. Data collection techniques used in this research is the data on validation results obtained from the validation instrument sheet filled out by the evaluator. The data for practicality level obtained from questionnaires that filled out by the evaluator and practitioners. Data for effectiveness obtained from a questionnaire of student's responses and mastery of student learning outcomes by instructional media based on MindManager. The data obtained from the study were analyzed using the criteria of validity, practicality, and effectiveness by Hobri. The research results of developing instructional media based on MindManager shows that the total value of the validation results by valuator are 4.42 and included in the valid category. The average level of practicality by valuator questionnaire was $91.33 \%$ and $90.66 \%$ by practitioners. The effectiveness of the media based on the student response was $96.6 \%$ gave a positive response and mastery of learning outcomes is $89.7 \%$ of the subjects achieved a minimum level of mastery of the material. Based on these results it can be concluded that the instructional media based MindManager developed by validity, practicality and effectiveness criteria.
\end{abstract}

Copyright (C) 2018 Universitas Negeri Medan. Artikel Open Access dibawah lisensi CC-BY-4.0 (https://creativecommons.org/licenses/by/4.0)

\section{How to Cite}

Nurlia, \& Anggo, S. (2018) Pengembangan Media Pembelajaran Berbasis MindManager Konsep Struktur dan Fungsi Organ Tumbuhan pada Siswa Sekolah Menengah Pertama. Jurnal Pendidikan Biologi, 8(1), 6-13.

\section{PENDAHULUAN}

Seiring dengan kemajuan teknologi di berbagai bidang, misalnya dalam teknologi komunikasi dan informasi pada saat ini, media pembelajaran memiliki posisi sentral dalam proses belajar dan bukan semata-mata sebagai alat bantu. Media pembelajaran memainkan 
peran yang cukup penting untuk mewujudkan kegiatan belajar menjadi lebih efektif dan efisien. Penggunaan media pembelajaran dikaitkan denga apa saja yang dapat dilakukan oleh media, yang mungkin tidak mampu dilakukan oleh guru atau guru melakukan kurang efisien (Jauhari, 2018).

Media pembelajaran setiap tahun selalu mengalami perkembangan, karena masingmasing media itu mempunyai kelemahan, berdasarkan penggunaannya perlu diadakan penemuan media baru dan pemanfaatan media yang telah diperbaharui. Penggunaan media dalam proses pembelajaran juga harus disesuaikan, oleh sebab itu pengajar harus dapat memilih media pembelajaran yang baik untuk digunakan saat mengajar. Media pembelajaran yang baik harus memenuhi beberapa kriteria, antara lain: kesesuaian dengan materi pembelajaran, kemudahan dalam penggunaan, dan menarik bagi peserta didik, sehingga tercapai tujuan pembelajaran yang optimal (Widada, 2010).

Berdasarkan hasil observasi di sekolah yaitu SMP Negeri 26 Makassar, SMP Negeri 27 Makassar, SMP Negeri 1 Tonra Kab. Bone dan SMP Negeri 1 Salomekko Kab. Bone, selama ini pada umumnya guru mengajar menggunakan media pembelajaran konvensional berupa papan tulis, gambar dan charta untuk membantu siswa dalam menguasai materi pelajaran namun, beberapa diantaranya telah menggunakan media berbantuan komputer tetapi masih sangat terbatas sehingga hasil belajar siswa masih rendah. Hal ini disebabkan karena dalam proses pembelajaran tersebut pembelajaran cenderung lebih terpusat pada guru dimana guru menjadi sumber belajar dalam proses pembelajaran dan siswa menjadi pasif dimana siswa hanya duduk mendengarkan penjelasan guru sambil membaca buku pegangan sehingga menyulitkan siswa dalam belajar mengingat, dan siswa merasa jenuh sehingga perhatian siswa dapat dengan mudah terpecah dalam proses pembelajaran. Jika ditinjau dari segi sarana dan prasarana, hampir disetiap sekolah sudah mempunyai komputer dan alat untuk memproyeksikan media yang jumlahnya cukup memadai untuk digunakan dalam proses pembelajaran serta siswa yang mempunyai keterampilan untuk mengoperasikan komputer. Namun, pada kenyataannya ketersediaan media pembelajaran yang inovatif masih sangat terbatas.

Hal tersebut yang menjadi dasar peneliti melakukan penelitian dan pengembangan media pembelajaran berbasis MindManager. Selain itu, peneliti ingin memberikan gambaran kepada guru-guru yang ada di sekolah, bahwa penggunaan media pembelajaran berbasis MindManager dapat meningkatkan hasil belajar siswa, karena dalam proses belajar mengajar dengan menggunakan media pembelajaran berbasis MindManager disajikan secara terstruktur akan lebih menarik perhatian siswa untuk berkonsentrasi pada isi pelajaran sehingga siswa mudah memahami dan mengingat materi yang telah diajarkan dan memungkinkan menguasai dan mencapai tujuan pembelajaran.

Kata media berasal dari bahasa Latin dan merupakan bentuk jamak dari kata medium yang secara harfiah berarti perantara atau pengantar. Media adalah segala sesuatu yang dapat digunakan untuk menyalurkan pesan dari pengirim ke penerima sehingga dapat merangsang pikiran, perasaan, perhatian dan minat siswa sedemikian rupa sehingga proses belajar terjadi. Alat bantu yang dipakai adalah alat bantu visual, misalnya gambar, model, objek dan alat-alat lain yang dapat memberikan pengalaman konkret, motivasi belajar serta mempertinggi daya serap dan retensi belajar siswa (Sadiman, 2009).

Menurut Kustandi \& Sutjipto (2011), kriteria yang patut diperhatikan dalam 
memilih media, yakni sesuai dengan tujuan yang ingin dicapai, tepat untuk mendukung isi pelajaran yang sifatnya fakta, konsep, prinsip, atau generalisasi, praktis, luwes, dan bertahan, guru terampil menggunakannya, mengelompokkan sasaran, dan mutu teknis.

Hasil penelitian Francis M. Dwyer menyebutkan bahwa setelah lebih dari tiga hari pada umumnya manusia dapat mengingat pesan yang disampaikan melalui tulisan sebesar $10 \%$, visual $30 \%$, audio visual $50 \%$, dan apabila ditambah dengan melakukan, maka akan mencapai $80 \%$. Dengan melihat hasil penelitan ini maka penggunaan multimedia interaktif dengan aspek animasinya yang menarik, mempunyai potensi yang sangat besar dalam membantu proses pembelajaran (Leksono, 2008).

Hasil penelitian dan pengembangan menunjukkan bahwa kualitas media pembelajaran berbasis komputer adalah baik. Hal tersebut didasarkan pada hasil penilaian oleh ahli media dan ahli materi, serta hasil uji coba lapangan. Ahli media memberikan penilaian dengan skor rata-rata 4,00, ahli materi memberikan penilaian dengan skor rata-rata 4,38, dan hasil uji coba lapangan diperoleh skor rata-rata 4,10. Selain itu, hasil belajar siswa menunjukkan bahwa terjadi peningkatan rata-rata skor pre-test sebesar 34,40 dari 25 siswa pada uji coba lapangan, dengan 19 siswa (76\%) telah mencapai ketuntasan belajar (Sudatha, 2010).

Menurut Buzan (2007), MindManager dapat menjadi suatu alternatif di samping metode konvensional yang dapat meningkatkan efektifitas pembelajaran karena membantu mengorganisir informasi dengan baik serta hanya menyajikan informasi dan konsep yang penting/inti saja, dapat meningkatkan tingkat partisispasi siswa dalam belajar karena suasana belajar menjadi lebih menarik dan menyenangkan karena bahan pelajaran dapar diringkas ke dalam bentuk yang menarik serta mudah untuk dipahami dan diingat, dapat membantu guru dalam menyampaikan materi pelajaran secara lebih efektif dan efisien yang pada akhirnya dapat meningkatkan hasil akademis siswa,dapat meringankan tugas siswa dan guru dalam menyelesaikan seluruh materi pelajaran dalam waktu lebih singkat namun tidak mempengaruhi kualitasnya.

Tujuan yang akan dicapai dalam penelitian ini adalah untuk mengembangkan media pembelajaran biologi konsep struktur dan fungsi organ tumbuhan berbasis MindManager yang valid, praktis dan efektif. Penelitian ini diharapkan dapat menjadi sumber informasi penting dalam efektifitas penerapan metode MindManager pada pelajaran biologi di Sekolah Menengah Pertama.

\section{METODE}

Jenis penelitian ini merupakan penelitian dan pengembangan (Research and Development). Model penelitian pengembangan yang dipilih adalah model penelitian dan pengembangan pendidikan yang dikembangkan oleh Borg and Gall (1983). Teknik pengambilan sampel dalam penelitian ini adalah random sampling. Secara operasional tahap-tahap kegiatan pengembangan media pembelajaran berbasis MindManager menurut Borg \& Gall adalah Penelitian dan pengumpulan informasi, pada tahap ini dilakukan dengan mengumpulkan data dari hasil wawancara langsung dengan guru mata pelajaran dan observasi di kelas serta pengamatan sarana dan prasarana di SMP Negeri 27 Makassar. Perencanaan,untuk menyiapkan peralatan dan bahan yang dibutuhkan dalam membuat media. Pengembangan bentuk produk awal, tahap perancangan bentuk awal produk yang mencakup bahan-bahan pembelajaran. Uji coba awal, peneliti membagikan instrumen validasi kepada para validator. Perbaikan 
produk awal, peneliti kembali merevisi media berdasarkan saran dari validator. Uji coba skala kecil, melaksanakan uji coba terbatas yang melibatkan siswa di kelas yang dilakukan oleh peneliti. Perbaikan produk akhir, melakukan perbaikan/ penyempurnaan terhadap hasil uji coba skala kecil/ terbatas apabila memang masih terdapat kekurangan di dalam media MindManager tersebut.

Kriteria yang menyatakan media pembelajaran memiliki derajat validitas yang baik, jika minimal tingkat validitas yang dicapai adalah tingkat valid. Media pembelajaran yang dikembangkan dalam penelitian ini dikatakan praktis apabila telah mencapai rata-rata tingkat kepraktisan di atas $80 \%$, dikatakan efektif jika memenuhi indikator apabila banyaknya siswa yang memberi respon positif lebih besar atau sama dengan $80 \%$ ( $\geq 80 \%$ ) dari jumlah subjek yang diteliti dan apabila $80 \%$ siswa yang mengikuti pembelajaran mampu mencapai tingkat penguasaan materi minimal sedang atau minimal $80 \%$ siswa yang mengikuti pembelajaran mampu mencapai skor minimal 60 (skor maksimal adalah 100).

\section{HASIL DAN PEMBAHASAN}

Hasil akhir dari media pembelajaran berbasis MindManager konsep struktur dan fungsi organ tumbuhan yang telah divalidasi oleh para validator ahli dan diujicobakan di sekolah merupakan desain operasional yang siap digunakan. Adapun hasil penelitian dan pengembangan media berbasis MindManager disajikan pada Tabel 1.

Tabel 1. Rangkuman hasil validasi keseluruhan aspek media pembelajaran berbasis MindManager oleh semua validator

\begin{tabular}{|c|c|c|}
\hline Komponen Media MindManager & Skor Rata-rata Penilaian & Kategori \\
\hline Kelayakan isi & 4,37 & Valid \\
\hline Kelayakan penyajian & 4,40 & Valid \\
\hline Bahasa & 4,44 & Valid \\
\hline Ukuran & 4,80 & Valid \\
\hline Desain tampilan media & 4,47 & Valid \\
\hline Desain isi media & 4,06 & Valid \\
\hline Rata-rata & 4,42 & Valid \\
\hline
\end{tabular}

Hasil analisis pada Tabel 1 menunjukkan bahwa kriteria kevalidan dari segi aspek kelayakan isi termasuk dalam kategori "Valid". Indikator penilaian untuk aspek ini menunjukkan bahwa materi yang ada didalam MindManager ini mampu menjabarkan substansi minimal (fakta, konsep, prinsip dan teori), memiliki kesesuaian antara materi dengan perkembangan ranah kognitif siswa, kesesuaian penyajian dengan indikator pencapaian hasil belajar, dukungan media terhadap penanaman konsep, kesesuaian konsep dengan tujuan belajar, kebenaran konsep, urutan penyajian konsep, kesesuaian gambar dengan animasi dalam menunjang penjelasan materi, dan kesesuaian pertanyaan materi dengan tujuan pembelajaran. Materi yang disajikan di dalam media pembelajaran berbasis MindManager tersebut dalam bentuk peta konsep sehingga mudah dipahami oleh siswa.

Menurut Septiana (2011), manfaat materi yang disajikan dalam bentuk peta konsep adalah dapat meningkatkan pemahaman siswa, karena peta konsep merupakan cara belajar yang mengembangkan proses belajar bermakna, dapat meningkatkan keaktifan dan kreatifitas berpikir siswa, dan akan memudahkan siswa dalam belajar. 
Kriteria kevalidan dari segi penyajian. termasuk dalam kategori "Valid". Nilai valid ini diperoleh dengan ketercapaian indikator keruntutan konsep, penyajian materi yang sesuai sistematika, pendahuluan yang sederhana, daftar isi, daftar pustaka, dan evaluasi yang memungkinkan siswa mengevaluasi kemampuannya sesuai Standar Kompetensi dan Kompetensi Dasar. Kriteria kevalidan dari segi aspek bahasa termasuk dalam kategori "Valid". Nilai valid ini diperoleh dari ketercapaian indikator penilaian dalam segi kelayakan bahasa dalam menyajikan materi dengan bahasa baku, memiliki keterbacaan yang jelas, adanya kemudahan dalam memahami bahasa yang digunakan, kalimat yang digunakan efektif, serta penggunaan kata sesuai dengan ejaan yang disempurnakan (EYD) sehingga siswa mudah untuk memahami materi yang disajikan; Kriteria kevalidan yang keempat adalah dari segi aspek ukuran.

Kriteria kevalidan untuk aspek bentuktermasuk dalam kategori "Valid". Indikator pencapaian nilai valid ini berupa tampilan ukuran media Full screen untuk setiap komputer dan kesesuaian ukuran main topic dan sub topic dengan jumlah isi (content) media, konsistensi penggunaaan ukuran huruf; Kriteria kevalidan dari segi aspek desain tampilan termasuk dalam kategori "Valid". Indikator pencapaian nilai valid ini berupa urutan tampilan media yang sesuai, dan petunjuk penggunaan yang sesuai. Media MindManager ini di dalamnya terdapat video dan animasi yang diputar melalui MpcStar, jadi media ini bekerja sama dengan software yang lain untuk mendukung media MindManager itu sendiri, hal ini mengungkapkan bahwa media memiliki hubungan erat antara berbagai unsur sehingga keseluruhannya berfungsi padu.

Multimedia merupakan suatu media belajar berisi program (software) pembelajaran yang bersifat interaktif terdiri dari gabungan antara teks, gambar, grafis, sound, animasi, movie, audio dan video yang dibuat dengan program aplikasi komputer dan diakses/ ditayangkan melalui bantuan komputer serta cara penyampaian interaktif yang dapat membuat suatu pengalaman belajar bagi siswa seperti dalam kehidupan nyata di sekitarnya (Priyanto, 2009).

Kriteria kevalidan dari segi aspek desain isi termasuk dalam kategori "Valid". Nilai valid ini diperoleh dengan ketercapaian indikator penilaian berupa tata letak tulisan dan ukuran tampilan yang seimbang, berdasarkan hal tersebut menunjukkan bahwa komponen-komponen pada media MindManager telah memiliki unsur proporsional atau unsur yang seimbang dalam penyajian materi antar main topic dan sub topic dengan tetap mempertimbangkan standar kompetensi dan kompetensi dasar sebagai satu kesatuan pada tampilannya.

Hasil penelitian menunjukkan bahwa media MindManager yang telah dikembangkan memiliki desain isi yang telah memenuhi indikator penilaian dari segi aspek kelayakan isi yakni telah mampu menjabarkan substansi minimal (fakta, konsep, prinsip dan teori), memiliki kesesuaian antara materi dengan perkembangan ranah kognitif siswa, kesesuaian penyajian dengan indikator pencapaian hasil belajar, dukungan media terhadap penanaman konsep, kesesuaian konsep dengan tujuan belajar, kebenaran konsep. Hal ini sesuai dengan yang dikemukakan oleh Sudjana (2010) bahwa taraf berfikir manusia mengikuti tahap perkembangan dimulai dari berfikir konkret menuju ke berfikir abstrak, dimulai dari berfikir sederhana menuju ke berfikir kompleks. Melalui media pembelajaran hal-hal yang abstrak dapat dikonkretkan dan hal-hal yang kompleks dapat disederhanakan.

Hasil penelitian juga menunjukkan bahwa media MindManager yang telah dikembangkan 
memiliki komponen kegrafikan yang telah memenuhi indikator penilaian dari segi kesederhanaan, kekonsistenan, keseimbangan, ukuran, dan tampilan desain yang baik. Sehingga media MindManager akan meningkatkan minat dan motivasi siswa terhadap materi pelajaran yang disajikan dan tidak membuat jenuhbahkan akan menyenangkan bagi penggunanya. Sebagaimana menurut Kustandi \& Sutjipto (2011) bahwa media komputer juga memberikan rangsangan yang cukup besar dalam meningkatkan motivasi belajar siswa

Secara umum, MindManager rini jika dilihat dari hasil validitas yang telah dilaksanakan maka media MindManager ini termasuk dalam kategori "Valid" $(4 \leq \mathrm{Va}<5)$, dimana nilai rata-rata total untuk semua indikator penilaian adalah $\bar{V}=4,42$. Berdasarkan kriteria kevalidan, maka dapat dikatakan perangkat pembelajaran tersebut telah memiliki derajat validitas yang tinggi dan layak untuk digunakan.

Tabel 2. Data kepraktisan media pembelajaran MindManager berdasarkan angket para ahli (validator) dan praktisi (guru)

\begin{tabular}{|c|c|c|c|}
\hline No & $\begin{array}{c}\text { Aspek yang dinilai } \\
\end{array}$ & Penilaian validator (\%) & Penilaian guru (\%) \\
\hline 1 & $\begin{array}{l}\text { Daya tarik media pembelajaran berbasis MindManager } \\
\text { yang dikembangkan }\end{array}$ & 86,67 & 93,33 \\
\hline 2 & $\begin{array}{l}\text { Kesederhanaan proses pengembangan media } \\
\text { pembelajaran berbasis MindManager }\end{array}$ & 93,33 & 80 \\
\hline 3 & $\begin{array}{l}\text { Kemudahan penggunaan media pembelajaran berbasis } \\
\text { MindManager dalam proses belajar mengajar }\end{array}$ & 93,33 & 86,67 \\
\hline 4 & $\begin{array}{l}\text { Media pembelajaran berbasis MindManager yang } \\
\text { dikembangkan sesuai dengan konsep materi }\end{array}$ & 93,33 & 93,33 \\
\hline 5 & $\begin{array}{l}\text { Penyajian materi dalam media pembelajaran berbasis } \\
\text { MindManager mudah dipahami }\end{array}$ & 100 & 93,33 \\
\hline 6 & $\begin{array}{l}\text { Tingkat keterandalan dari media pembelajaran berbasis } \\
\text { MindManager yang dikembangkan }\end{array}$ & 86,67 & 93,33 \\
\hline 7 & $\begin{array}{l}\text { Keefisienan waktu yang digunakan dalam penyajian } \\
\text { materi dengan menggunakan media pembelajaran } \\
\text { berbasis MindManager }\end{array}$ & 93,33 & 93,33 \\
\hline 8 & $\begin{array}{l}\text { Media pembelajaran berbasis MindManager yang } \\
\text { dikembangkan memiliki tampilan yang jelas }\end{array}$ & 93,33 & 100 \\
\hline 9 & $\begin{array}{l}\text { Bahasa yang digunakan pada media pembelajaran } \\
\text { berbasis MindManager bersifat komunikatif }\end{array}$ & 86,67 & 93,33 \\
\hline 10 & $\begin{array}{l}\text { Nilai ekonomis dari media pembelajaran berbasis } \\
\text { MindManager yang dikembangkan }\end{array}$ & 86,67 & 80 \\
\hline & $\begin{array}{l}\text { Total } \\
\end{array}$ & 91,33 & 90,66 \\
\hline
\end{tabular}

Hasil analisis untuk Tabel 2 menunjukkan bahwa hasil penelitian rata-rata tingkat kepraktisan media pembelajaran berbasis MindManager yang dikembangkan adalah 91,33\% dari para ahli (validator) dan 90,66\% dari para praktisi (guru). Berdasarkan data tersebut maka dapat disimpulkan bahwa media pembelajaran berbasis MindManager yang telah dikembangkan dapat digunakan jika ditinjau dari segi kepraktisan.
Media pembelajaran berbasis MindManager dikatakan praktis jika para ahli (validator) dan praktisi menyatakan bahwa media pembelajaran berbasis MindManager tersebut dapat digunakan dengan sedikit atau tanpa revisi. Cara memberikan penilaian kepraktisan pada media berbasis MindManager yang telah dibuat yaitu dengan memberikan angket tentang penilaian media pembelajaran berbasis MindManager secara umum kepada para ahli (validator) dan praktisi. Media 
pembelajaran yang dikembangkan dalam mencapai rata-rata tingkat kepraktisan di atas penelitian ini dikatakan praktis apabila telah $80 \%$ (Yamasari, 2010).

Tabel 3. Rangkuman hasil respon siswa terhadap keseluruhan aspek media pembelajaran berbasis MindManager

\begin{tabular}{|c|c|c|c|}
\hline \multirow{2}{*}{ Sub komponen } & \multicolumn{3}{|c|}{ Penilaian (\%) } \\
\hline & Sangat baik & Baik & Kurang baik \\
\hline Penyajian materi & 43,6 & 56,4 & - \\
\hline Bahasa yang digunakan & 25,7 & 69,2 & 5,1 \\
\hline Waktu penyajian & 30,7 & 66,7 & 2,6 \\
\hline Kegunaan media & 51,2 & 48,8 & - \\
\hline Ukuran tampilan & 46,2 & 51,2 & 2,6 \\
\hline Kombinasi background & 41 & 48,4 & 10,2 \\
\hline Kualitas gambar, video dan animasi & 66,7 & 33,3 & - \\
\hline Komposisi warna & 53,8 & 38,5 & 7,7 \\
\hline Kejelasan huruf/kalimat & 48,7 & 48,7 & 2,6 \\
\hline $\begin{array}{l}\text { Rata-rata } \\
\end{array}$ & $45,3 \%$ & $51,3 \%$ & $3,4 \%$ \\
\hline
\end{tabular}

Hasil analisis untuk Tabel 3 menunjukkan bahwa hasil penelitian rata-rata persentase respon siswa terhadap isi keseluruhan media pembelajaran berbasis MindManager ini adalah 96,6\% siswa yang memberikan respon positif dalam hal ini kriteria sangat baik dan baik. Data yang diperoleh dari hasil pembagian angket respon siswa terhadap media pembelajaran menunjukkan bahwa media pembelajaran berbasis MindManager ini telah memenuhi kriteria keefektifan berdasarkan respon positif yang diberikan oleh siswa.
Menurut Bakri (2011), media pembelajaran adalah segala sesuatu yang digunakan untuk menyalurkan pesan, dan dapat merangsang pikiran, perasaan, perhatian, dan kemauan peserta didik sehingga dapat mendorong terjadinya proses belajar yang disengaja, bertujuan dan terkendali. Penggunaan media secara kreatif akan memungkinkan audien untuk belajar lebih baik dan dapat meningkatkan performan mereka sesuai dengan tujuan yang ingin dicapai.

Tabel 4. Hasil tes belajar siswa terhadap media pembelajaran berbasis MindManager

\begin{tabular}{ccc}
\hline Kriteria Pencapian Hasil Belajar & Jumlah Siswa & Persentase \\
\hline $60-100$ & 35 orang & $89,7 \%$ \\
$<60$ & 4 orang & $10,3 \%$ \\
\hline
\end{tabular}

Hasil analisis untuk Tabel 4 menunjukkan bahwa hasil penelitian ketuntasan hasil belajar menunjukkan bahwa dari 39 siswa, 35 siswa atau $89,7 \%$ dari keseluruhan subjek penelitian mampu mencapai tingkat penguasaan materi minimal dan 4 siswa atau $10,3 \%$ dari subjek penelitian yang belum mencapai tingkat penguasaan minimal. Data tersebut menunjukkan bahwa media pembelajaran berbasis
MindManager telah memenuhi kriteria keefektifan.

Menurut Isa (2016) nilai dan kegunaan media pembelajaran dapat mempertinggi proses pembelajaran dan hasil belajar yang dicapai dalam proses pembelajar-an. Penggunaan alat-alat bantu mengajar, peraga pendidikan dan media pembelajaran di sekolah-sekolah mulai menyesuaikan dengan 
perkembangan teknologi. Hal yang perlu diperhatikan adalah semua peralatan dan perlengkapan sekolah tersebut harus disesuaikan dengan tuntutan kurikulum dan materi, metode dan tingkat kemampuan siswa untuk mencapai tujuan pembelajaran. Perkembangan teknologi informasi telah mempengaruhi penggunaan berbagai jenis media sebagai alat bantu dalam proses pembelajaran. Maka para pengajar diharapkan dapat menggunakan alat-alat atau perlengkapan tersebut secara efektif dan efesien dalam pembelajaran.

Guna meningkatkan efektivitas dan efisiensi pembelajaran, perlu dikembangkan berbagai model pembelajaran yang kreatif dan inovatif. Hal ini perlu dilakukan agar proses pembelajaran tidak terkesan kurang menarik, monoton dan membosankan sehingga akan menghambat terjadinya transfer of knowledge. Oleh karena itu peran media dalam proses pembelajaran menjadi penting karena akan menjadikan proses pembelajaran tersebut menjadi lebih bervariasi dan tidak membosankan (Muhson, 2010).

\section{KESIMPULAN}

Berdasarkan hasil penelitian dapat disimpulkan bahwa media pembelajaran berbasis MindManager konsep struktur dan fungsi organ tumbuhan dinyatakan valid atau memiliki tingkat validitas yang tinggi dengan nilai rata-rata total kevalidan media adalah 4,42. Rata-rata tingkat kepraktisan dari para ahli (validator) adalah $91,33 \%$ dan dari para praktisi (guru) adalah 90,66\%. Keefektifan media berdasarkan hasil respon siswa adalah 96,6\% memberi respon positif dan berdasarkan ketuntasan hasil belajar $89,7 \%$ dari subjek penelitian mencapai tingkat penguasaan materi minimal. Media pembelajaran
MindManager yang dikembangkan memenuhi kriteria kevalidan, kepraktisan dan keefektifan.

\section{DAFTAR PUSTAKA}

Buzan, T. (2007). Buku Pintar Mind Map. Jakarta. Gramedia.

Bakri, H. (2011). Desain Media Pembelajaran Animasi Berbasis Adobe Flash CS3 Pada Mata Kuliah Instalasi Listrik 2. Jurnal Medtek, 3(2), 34.

Jauhari, M. I. (2018). Peran Media Pembelajaran dalam Pendidikan Islam. Jurnal Piwulang, 1(1), 54-67.

Kustandi, C., \& Sutjipto, B. (2011). Media Pembelajaran: Manual dan Digital. Bogor: Ghalia Indonesia.

Leksono, S. M. (2008). Pengembangan Media Pembelajaran Berbantuan Komputer (PBK) untuk SMA pada Materi Amfibi. Sippendidikan Kemdikbud.go.id.

Muhson, A. (2010). Pengembangan Media Pembelajaran Berbasis Teknologi Informasi. Jurnal Pendidikan Akuntansi Indonesia, 8 (2), 1-10.

Priyanto, D. (2009). Pengembangan Multimedia Pembelajaran Berbasis Komputer. Insania, 14(1), 92-110.

Sadiman, A., Rahardjo, R., Haryono, A., \& Rahardjito (2009). Media Pendidikan: Pengertian, Pengembangan, dan Pemanfaatannya. Jakarta. Rajawali Pers.

Akram, N. (2014). Keefektifan Penggunaan Media Peta Konsep Pohon Jaringan Pada Pembelajaran Menulis Cerpen Siswa Kelas X SMA Negeri 1 Labakkang Kabupaten Pangkep. Skripsi. Program Studi Pendidikan Bahasa, Kekhususan Bahasa Indonesia, Program Pascasarjana, Universitas Negeri Makassar.

Sudjana, N., \& Rivai, A. (2010). Media Pengajaran. Bandung. Sinar Baru Algesindo.

Isa, A. (2016). Keefektifan pembelajaran berbantuan multimedia menggunakan metode inkuiri terbimbing untuk meningkatkan minat dan pemahaman siswa. Jurnal Pendidikan Fisika Indonesia, 6(1), 58-62.

Widada, H. R. (2010). Mudah Membuat Media Pembelajaran Multimedia Interaktif untuk Guru dan Profesional. Yogyakarta. Pustaka Widyatama.

Yamasari, Y. (2010). Pengembangan Media Pembelajaran Matematika Berbasis ICT yang Berkualitas. In Seminar Nasional Pascasarjana XITS. FMIPA UNESA. 